\title{
The effect of finasteride on spermatogenesis of Mesocricetus auratus ${ }^{1}$
}

\author{
Impacto da finasterida na espermatogênese do Mesocricetus auratus
}

\author{
Dimas José Araújo Vidigal', Alcino Lázaro da SilvaII, Luiz Mauro Andrade da Fonseca ${ }^{\mathrm{III}}$, Anilton Cesar Vasconcelos ${ }^{\mathrm{IV}}$, \\ Dilermando Fazito de Resende ${ }^{\mathrm{VI}}$, Felipe Eduardo Costa Vidigal ${ }^{\mathrm{VI}}$. \\ ${ }^{\mathrm{I}}$ Fellow PhD degree in Surgery, Medicine School, Federal University of Minas Gerais (UFMG), Brazil. \\ II Emeritus Professor, UFMG, Brazil. \\ III Full Professor, Department of Pathology, Medicine School of Barbacena, “José Bonifácio” Foundation (FAME-FUNJOB), Minas Gerais, Brazil. \\ Iv Associate Professor, Laboratory of Apoptosis, Department of General Pathology, Institute of Biological Science, UFMG, Brazil. \\ ${ }^{v}$ Full Professor, Scientific Methodology, FAME-FUNJOB, Minas Gerais, Brazil

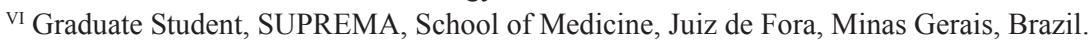

\begin{abstract}
Purpose: To study the effect of finasteride on the spermatogenesis of adult Mesocricetus auratus. Methods: Twenty adult hamsters were evaluated. The animals were one year-older, and were randomly divided in 2 different groups: control group with ten animals $(n=10)$ and experimental group also with ten animals $(n=10)$. The animals in the experimental group were shot 7.14 $\mathrm{ng} / \mathrm{mL}(0.5 \mathrm{~mL})$ of finasteride by $100 \mathrm{mg} / \mathrm{Kg}$, subcutaneously in the dorsal region three times per week during 90 days. This dose correspondes to $5 \mathrm{mg}$ of the drug used in adult men for the treatment of benign prostatic hyperplasia (BPH). After three months, the animals were anesthetized through association of $200 \mathrm{mg} / \mathrm{kg}$ ketamine chloridrate and $2.5 \mathrm{mg} / \mathrm{kg}$ of diazepan and were dead through hypovolemia.. The testis removed along with the whole genitourinary apparel were fixed with $10 \%$ formalin and submitted to histological analisys by optical microscopy. The hematoxilin-eosin (HE) method was used to stain the slides. Results: The mean weight of animals in the control group before death was $129.0 \pm 18$.8gr. The mean weight of animals in experimental group was $145.0 \pm 15.25 \mathrm{gr}$. The mean age of animals in control group before death was $15.2 \pm 1.13$ months. The mean age of animals in experimental group before death was $17.16 \pm 0.82$ months. The mean difference in weight between both groups was not statistical significant $(\mathrm{p}=0.0514)$. The totality of animals in control group $(100 \%)$ presented no tubular alterations and showed no disturbancy in the spermatogenesis stages. Four animals $(40 \%)$ in the experimental group showed hypotrophy of the seminiferous tubules and six $(60 \%)$ showed normal spermatogenesis, however reduced compared to control group. There was statiscally significant difference $(p=0.043)$ between the control and experimental group related to testicular alterations. Conclusion: The animals that were administered finasteride showed significant tubules atrophy and spermatogenesis reduction compared to control group.
\end{abstract}

Key words: Mesocricetus. Finasteride. Testis. Spermatogenesis.

\section{RESUMO}

Objetivo: Estudar o impacto da finasterida na espermatogênese do Mesocricetus auratus, adulto. Métodos: Foram avaliados 20 hamsters adultos, com idades superiores a 1 ano, distribuídos em dois grupos: grupo controle com dez animais (n=10) e grupo experimental também com dez animais $(\mathrm{n}=10)$. No grupo experimental foi aplicado $7,14 \mathrm{ng} / \mathrm{mL}(0,5 \mathrm{~mL})$ de finasterida por $100 \mathrm{mg} / \mathrm{Kg} /$ peso, subcutâneo (SC), na região dorsal do animal, três vezes por semana por 90 dias, dose correspondente a $5 \mathrm{mg}$ da droga usada em homens adultos, para tratamento da hiperplasia benigna da próstata (HBP). No final de três meses, esses Hamsters foram mortos por hipovolemia, após serem anestesiados com cloridrato de quetamina, na dosagem de $200 \mathrm{mg} / \mathrm{kg}$ juntamente com diazepam, na dosagem de $2,5 \mathrm{mg} / \mathrm{kg}$. Os testículos foram retirados em monobloco juntamente com todo o aparelho geniturinário, fixados em formalina a $10 \%$ e encaminhados à histotécnica para posterior análise histológica em microscópico óptico. Foram usadas para coloração das lâminas a hematoxilina e eosina (HE). Resultados: Quando foram mortos, os Hamsters do grupo de controle pesaram em média 129,0g e desvio padrão (DP) de 18,8g. O grupo de experimento apresentou média de peso de 145,0g e DP de 15,25g. A idade dos animas de controle quando foram mortos apresentou média de 15,2 meses e DP de 1,13 meses. Os animais de experimento apresentaram média de idade de 17,16 meses e DP de 0,82. A diferença das médias de peso entre os dois grupos não teve significado estatístico ( $p=0,0514)$. Os animais $(100 \%)$ do grupo controle não tiveram alterações tubulares e apresentaram todas as etapas da espermatogênese normais. Quatro animais (40\%) do grupo de experimento apresentaram hipotrofia dos túbulos seminíferos, e seis $(60 \%)$ desses animais apresentaram espermatogênese normal, mas diminuída em relação ao grupo controle. Do ponto de vista estatístico houve significância $(p=0,043)$ entre o grupo de experimento e controle em relação às alterações testiculares. Conclusão: Os animais em uso de finasterida apresentaram atrofia tubulares significativas e diminuição da espermatogênese em comparação com o grupo-controle.

Descritores: Mesocricetus. Finasterida, Testículo. Espermatogênese.

1. Research performed at Post-Graduation Program in Surgery, Medicine School, Federal University of Minas Gerais (UFMG) and Laboratory of Apoptosis, Department of General Pathology, Institute of Biological Science, UFMG, Institute of Bio-Science, Presidente “Antônio Carlos” University (INBIO-UNIPAC). 


\section{Introduction}

Finasteride is a synthetic inhibitor of 5- $\alpha$-reductase, an enzyme that changes testosterone into dihydrotestosterone (DHT). DHT is an active metabolite of testosterone, much more powerful than the last ${ }^{1}$.

Two different male steroid hormones secreted by the testis were isolated from the venous blood: testosterone and 4androsterone-3,17-dione. However, the amount of testosterone is larger than the second hormone, so that testosterone can be considered as the only significant hormone responsible for the effects caused by male hormones. In the testis, both hormones are produced by the insterstitial cells of Leydig, which are located in the interstitial space between the seminiferous tubules ${ }^{1}$.

The testosterone that is released by the testis circulates in the blood for no longer than fifteen to thirty minutes, until it is fixed onto the tissues, or broken down into inactive substances to be excreted right after ${ }^{1}$. The share of testosterone fixed on the tissues is converted, inside the cells; into DHT by the 5 - $\alpha$-reductase ${ }^{1}$. This enzyme is responsible for the conversion of testosterone into DHT. As DHT, testosterone acts inside the cells ${ }^{1,2}$, it is assumed that DHT, after connecting with a plasmatic receptor, is transferred to the cellular nucleus, causing increased activity of the polymerase ribonucleic acid (polymerase RNA) and consequently, an increased synthesis of RNA and specific proteins ${ }^{2}$.

Spermatogenesis is a sequence of events that is dependent on testosterone, which leads the primitive germ cells to become spermatozoons. It starts in puberty when high levels of testosterone are released and it keeps occurring even in senescence ${ }^{1}$.

There are two types of 5- $\alpha$-reductase: type 1 found in the skin and liver, and type 2 found in the genitourinary system, including the prostate ${ }^{3}$. The sexual impotence is the main side effect from using finasteride, followed by a reduction in the ejaculated volume ${ }^{4}$. However, studies have shown side effects from the use of finasteride similar to the patients who used placebo ${ }^{5}$.

Clinical studies have shown that the use of finasteride in a $5 \mathrm{mg}$ dose, once a day, decrease the volume of prostate and improve the symptoms of benign hyperplasia obstructiving this gland $^{6}$. The $1 \mathrm{mg} /$ day dose used in the treatment of inherited androgenic alopecia, decreases the progress in hair loss and increase hair growth of ${ }^{7}$

Because of its influence on the metabolism of androgens, there is some worry, regarding its use, especially in patients at fertile age ${ }^{8}$. The effects of finasteride on the spermatogenesis have been studied in depth when the quality of the ejaculated is evaluated and just a few studies have been published on the action of finasteride at cellular level on the testis.

The aim of this paper is to increase and improve the knowledge on this field of this subject. Therefore, this study is referred to the impact of finasteride on the spermatogenesis of adult Mesocricetus auratus.

\section{Methods}

This work began after its approval by the board of ethics in research of the Presidente "Antonio Carlos" University (CEP-UNIPAC).

Twenty adult hamsters, older than 1 year, were evaluated. They were divided into two groups: the control group with ten animals $(n=10)$ and the experimental group, also with ten animals $(\mathrm{n}=10)$. Those animals were obtained from the animal house of the Bio-science Institute at Presidente "Antonio Carlos" Magnus Campus University (INBIO-UNIPAC).

The animals were put in plastic cages with $40 \times 60 \times 20 \mathrm{~cm}$. Each cage had two animals and were lined with appropriate sawdust, for the hamster's accommodation.

The hamsters were fed in an ad libitum alimentation: special food made for hamsters, seeds of sunflower, peanut and corn. It was also offered to the animals, ad libitum and drinkable water from a suction fountain. All the animals were exposed to indirect sunlight for twelve hours in a $21^{\circ} \mathrm{C}$ room.

In the experimental group, were shot $7.14 \mathrm{ng} / \mathrm{mL}$ $(0.5 \mathrm{~mL})$ of finasteride by $100 \mathrm{mg} / \mathrm{Kg}$, subcutaneously (SC) in the dorsal region of the animal for three times per week during ninety days (Figure 1). This dose corresponds to $5 \mathrm{mg}$ of the drug used in adult men $6(70 \mathrm{Kg})$ for the treatment of benign prostatic hyperplasia (BPH).

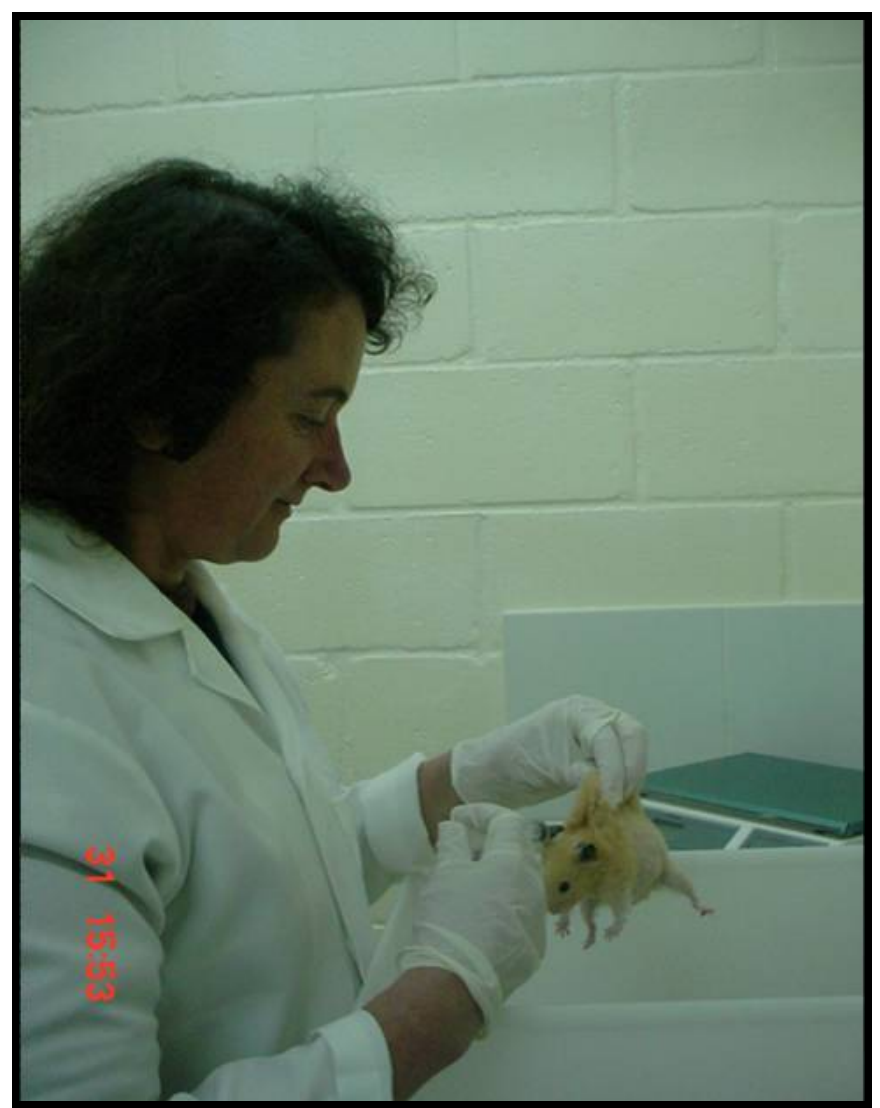

FIGURE 1 - Digital picture shows subcutaneously (SC) finasteride shot in the dorsal region of the animal ( INBIO-UNIPAC, 2006, Dec.).

After three months the animals died due to hypovolemia, after being anesthetized with $200 \mathrm{mg} / \mathrm{kg}$ of ketanine chloridrat and $2.5 \mathrm{mg} / \mathrm{kg}$ of diazepam ${ }^{9}$. 
The testis were removed along with all the genitourinary system and fixed with $10 \%$ formalin. After that, they were submitted to histological analysis by optical microscopy. The hematoxilin-eosin method was used to produce a slide stain.

\section{Results}

It was found that values of mean weight after death for the animals in the control group was $129.0 \pm 18.8 \mathrm{~g}$ and for the animals in the experimental group was $145.0 \pm 15.25 \mathrm{~g}$. The difference between the means of weight of the two tested groups did not show statistical significance, $p>0.05$. The animals in the control group had a mean age of $15.2 \pm 1.13$ months at the death, while this value was $17.6 \pm 0.82$ months for the experimental group.

Tubular changes were not found in the animals in the control group, and all of them showed normal spermatogenesis stages (Figure 2).

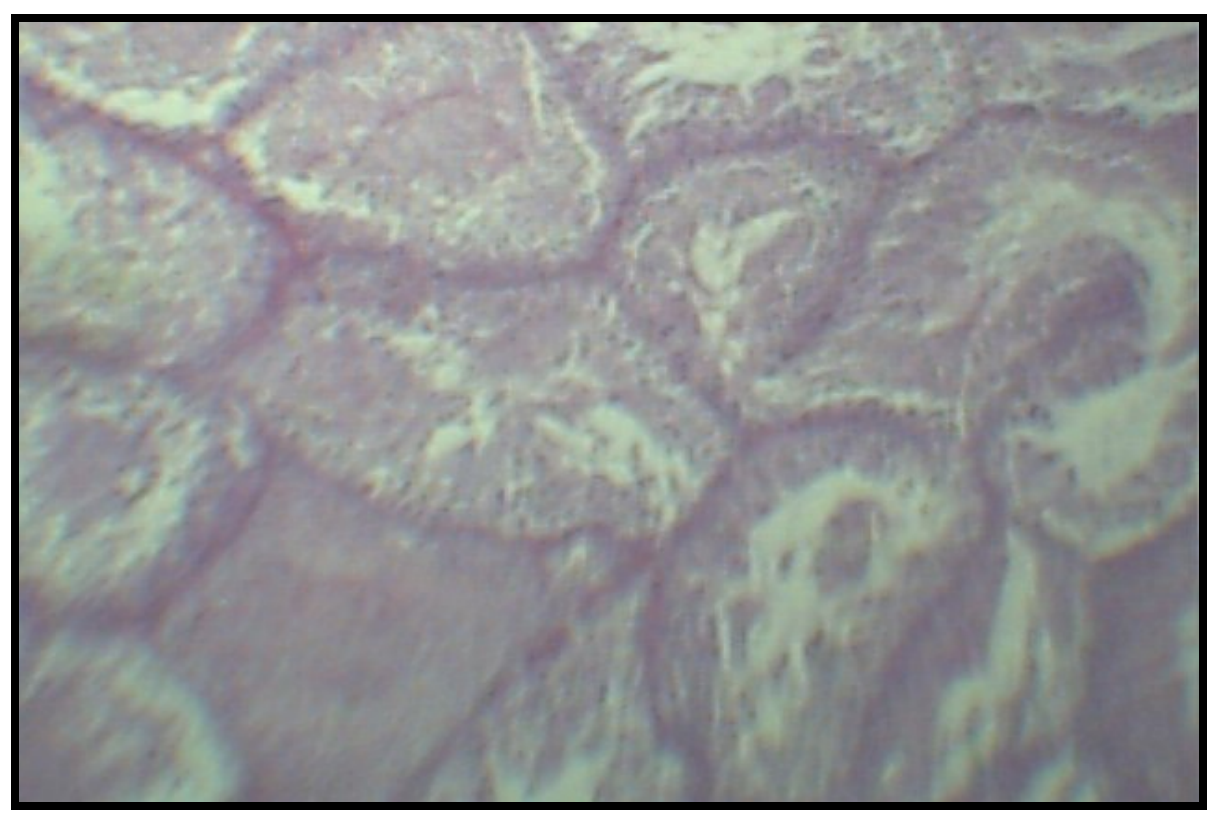

FIGURE 2 - Photomicrography of normal seminiferous tubules of an adult hamster.

Four animals in the experimental group showed seminiferous tubules hypotrophy (Figures 3 to 4 ) and six presented normal spermatogenesis, although this spermatogenesis process was reduced compared to the animals in the control group (Figures 5 to 6 ).

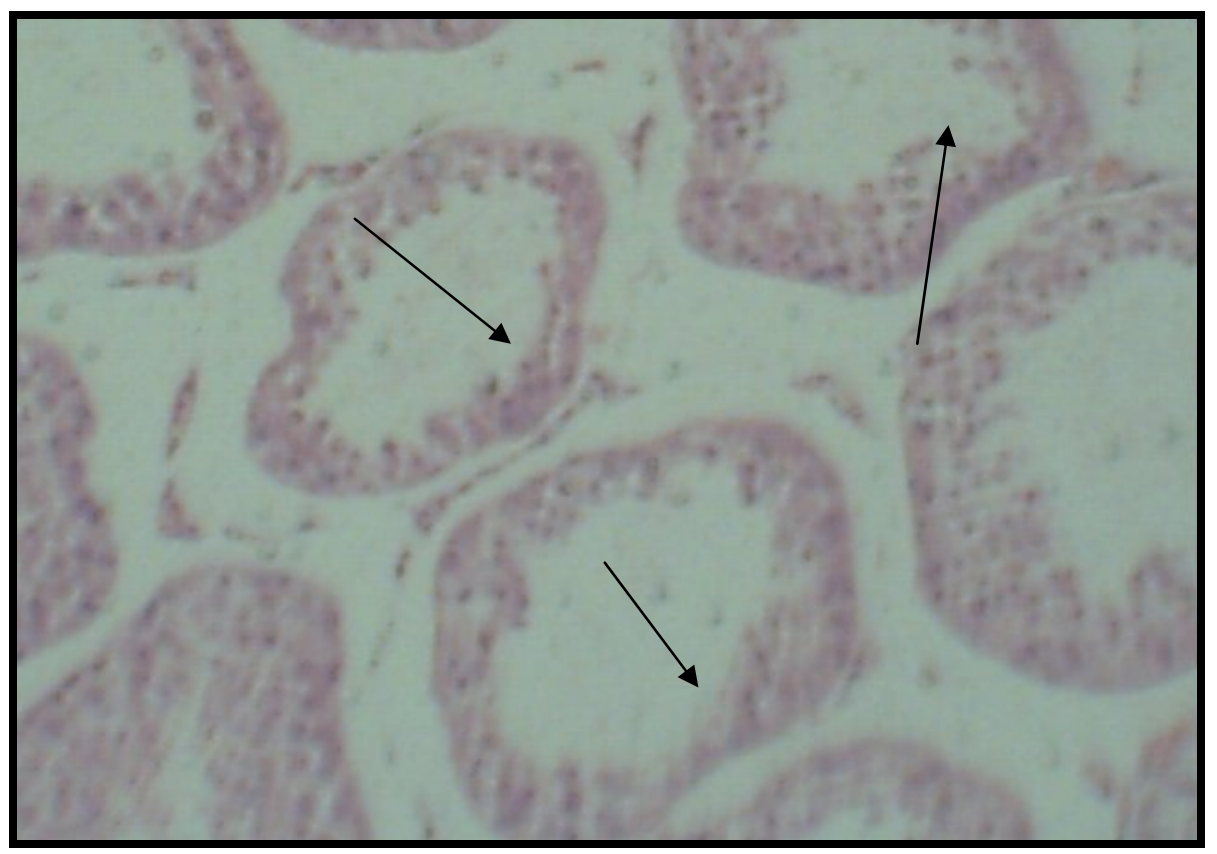

FIGURE 3 - Photomicrography of an adult hamster seminiferous tubules after treatement with finasteride. Remarcable seminiferous tubules atrophy (arrows) (HE 10x). 


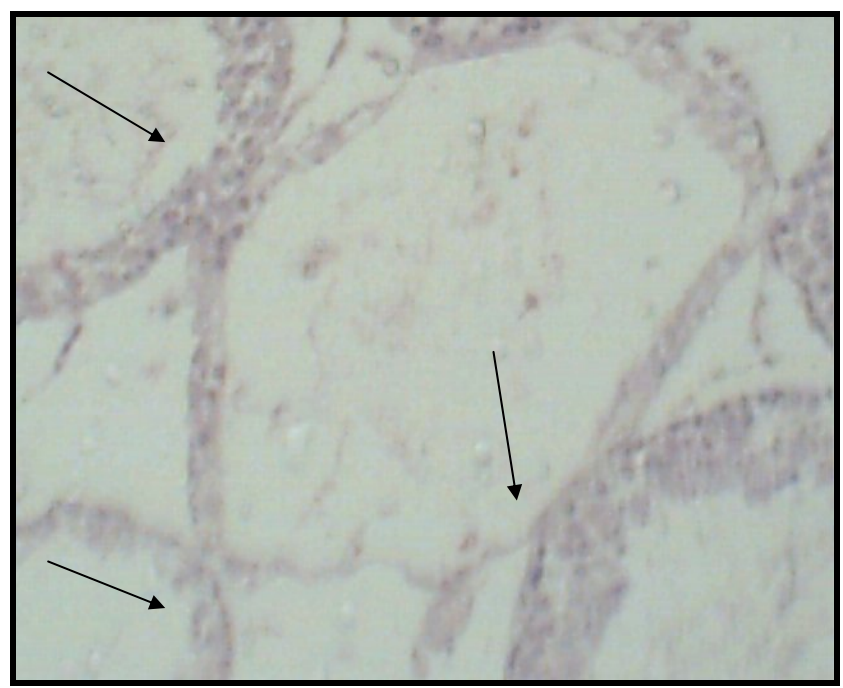

FIGURE 4 - Photomicrography of an adult hamster seminiferous tubules after treatement with finasteride. Remarcable seminiferous tubules atrophy (arrows) (HE 10x).

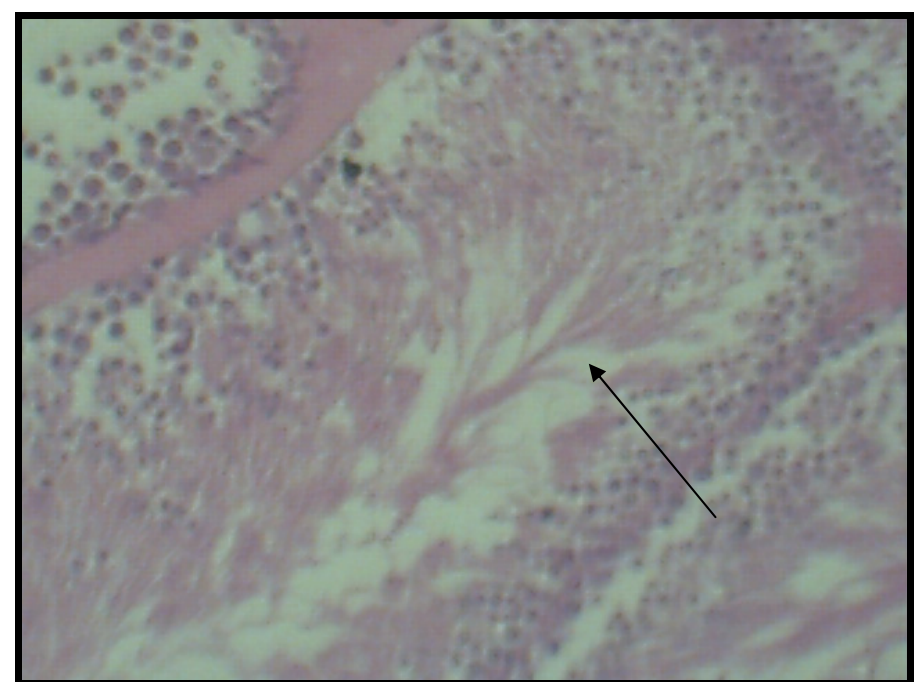

FIGURE 5 - Photomicrography of a seminiferous tubule of an adult hamster of the control group showing all the stages of the spermatogenesis and the plenty of spermatozoids inside the lumen (arrow) (HE 40x).

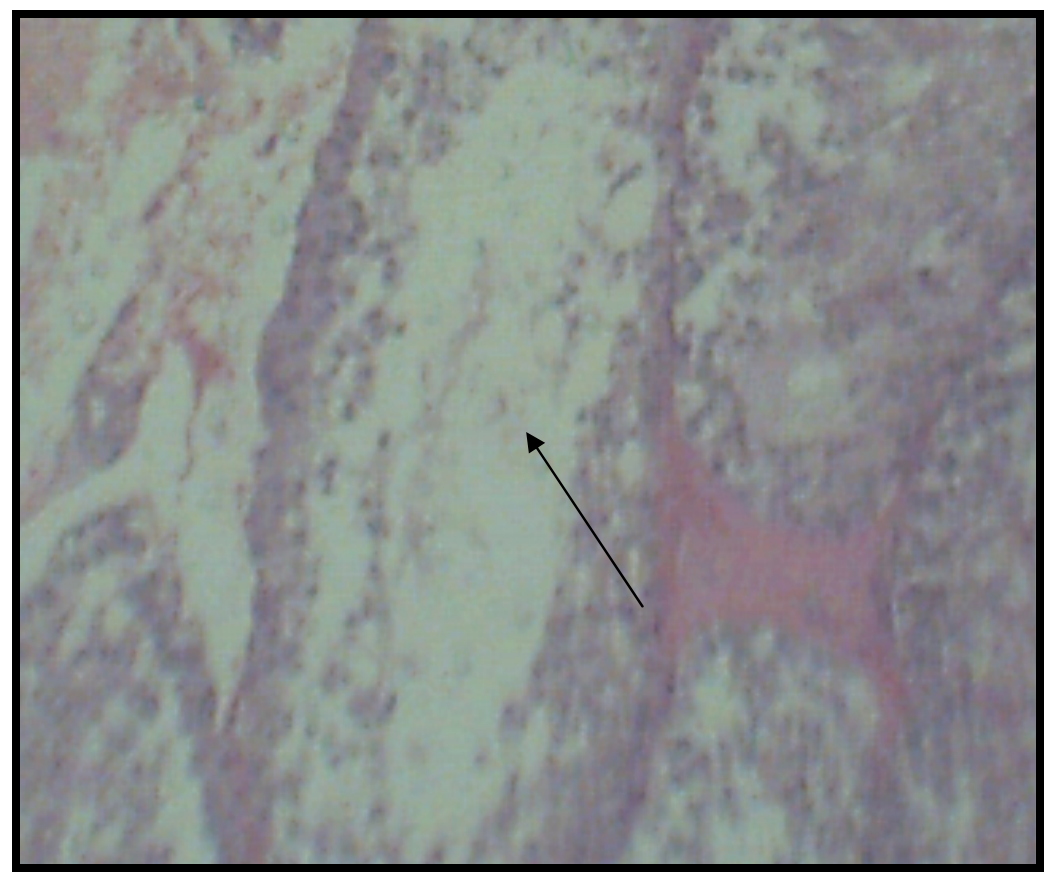

FIGURE 6 - Photomicrography of an adult hamster of the experimental group. Note the reduction in the spermatogenesis compared to control group (arrow) (HE 10x).

There was statistically significant difference $(p<0.05)$ in the testicular alterations between the two groups tested.

\section{Discussion}

Overstreet et al. ${ }^{10}$ investigating humans and Rhoden et al. ${ }^{11}$ investigating rats, did not show any alterations in the spermatogenesis after treatment with finasteride. Overstreet et $a l .{ }^{10}$ evaluated the ejaculate from young men under use of finasteride $1 \mathrm{mg}$ and compared them to a control group. No histological assessment of the seminiferous tubules was performed. The Wistar rats were provided by Rhoden et al. ${ }^{11}$, and they received finasteride $2 \mathrm{mg}$ in a saline solution. It was difficult to accurately evaluate the absorption of the medication, fact that might have influenced the results. In this study, to certificate the adequate absorption of medication the finasteride was injected subcutaneously (SC) in the experimental group, thus, providing liability to results.

Studies have shown that only one dose of $0.5 \mathrm{mg}$ of finasteride causes a $65 \%$ reduction in plasma dihydrotestosterone (DHT). This effect can remain for five to seven days ${ }^{12}$. After 14 days of treatment discontinuity the levels of finasteride returned to baseline ${ }^{12,13}$. In this investigation the experimental animals were administered finasteride three times per week.

The histological analysis confirmed the drug action in 
the target organs, such as testis, suggesting that the therapeutic use of finasteride in longer intervals could provide the same therapeutic benefits to patients, with a lower cost. It could also reduce the adverse drug effects possibly caused by drug accumulation in the body.

Currently, finasteride is used both for the treatment of BPH and for the treatment of androgenic alopecia ${ }^{7}$. The results of the present study show deleterious effects in spermatogenesis in the testis of Hamsters that received a finasteride dose corresponding to a $5 \mathrm{mg}$ used in human treament. Therefore, further invastigation must be done for safe application of this medication, specially in young men seeking for better esthetic results, who are in fertile age. It must be clarified to the patient the possible effects of finasteride on spermatogenesis. When choosing this medication the risks and benefits must be highly evaluated.

Further studies should be performed in order to clarify the safe dose of finasteride to be used, as well as the administration interval.

\section{Conclusion}

The animals treated with finasteride showed significant changes of the testicular seminiferous tubules as well as in the spermatogenesis when compared to the control group.

\section{References}

1. Guyton AC. Tratado de fisiologia médica. 4ed. Guanabara Koogan: Rio de Janeiro; 1973.

2. Silva P. Farmacologia. 4ed. Guanabara Koogan: Rio de Janeiro: 1994.

3. Thigpen AE, Silver RI, Guileyardo JM. Tissue distribuition and ontogeny of steroid 5-alpha-reductase isozyme expression. J Clin Invest. 1993; 92: 903-10.

4. Netto MR, Netto Junior NR. Avaliação e tratamento da hiperplasia de próstata benigna. J. Br. Urol. 1998; 24(3):184.

5. Gormley GJ, Stoner E, Bruskewitz RC, Imperato-McGinley J, Walsh PC, McConnell JD, Andriole GL, Geller J, Bracken
BR, Tenover JS, Vaughan ED, Pappas F, Taylor A, Binkowitz B, Ng J; Finasteride Study Group. The effect of finasteride in men with benign prostatic hyperplasia. 1992; J Urol. 2002 Feb;167(2 Pt 2):1102-7.

6. McConnell JD, Bruskewitz R, Walsh P, Andriole G, Lieber M, Holtgrewe HL, Albertsen P, Roehrborn CG, Nickel JC, Wang DZ, Taylor AM, Waldstreicher J. The effect of finasteride on the risk of acute urinary retention and the need for surgical treatment among men with benign prostatic hyperplasia: finasteride long-term efficacy and safety study group. N Engl J Med. 1998; 338:557-63.

7. Netto Junior CC. Alopécia androgênica e finasterida. JBM. 1999; 76(5):39-40.

8. Glina S, Neves PA, Saade R, Netto NR, Soares JB, Galuppo AG. Infertilidade masculina associada ao uso de finasterida. Rev Hosp Clin. 2004; 59(4):203-5.

9. Vidigal DJA, Silva LA, Fonseca LMA, Resende DF. Técnica para obtenção do aparelho genitourinário e dosagem do PSA (Prostate Specific Antigen) no Hamster Sírio, Mesocricetus auratus. Acta Cir Bras. 2004; 19(6): 603-8.

10. Overstreet JW, Fuh VL, Gould J, Howards SS, Lieber MM, Hellstrom W, Shapiro S, Carrole P, Corfman RS, Petron S, Lewis R, Toth P, Shown T, Rov J, Jarow JP, Bonilla J, Jacobsen CA, Wang DZ, Kaufman KD. Chronic treatment with finasteride daily does not affect spermatogenesis or semen production in young men. J Urol. 2000; 164(4):1319-20.

11. Rhoden EL, Gobbi D, Menti E, Rhoden C, Talöken C. Effects of the chronic use of finasteride on testicular weight and spermatogenesis in Wistar rats. Braz J Urol. 2002 jun; 89 (9): 961-3.

12. Ohtawa M, Morikawa H, Shimazaki J. Pharmacokinetics and biochemical efficacy after single and multiple oral administration of N-(2-methyl-2 propyl)-3-oxo-4-aza-5alfha-androst1-ene-17-beta-carboxamide, a new type of specific competitive anhibitor of testosterone 5alpha-reductase, in volunteers. Eur J Drug Metab Pharmacokinet. 1991;16(1): 15-21.

13. Stoner E. The clinical development of a 5-alpha-reductase inhibitor, finasteride. J Steroid Biochem Mol Biol. 1990; 37 : $375-8$.

\section{Correspondence:}

Dimas José Araújo Vidigal

Rua Augusto Justi, 74

36201-613 Barbacena-MG Brazil

Phone/Fax: (55 32)3331-0124

dimas@,barbacena.com.br
Conflict of interest: none Financial source: none

Received: November 27, 2007

Review: January 29, 2008

Accepted: February 25, 2008

\section{How to cite this article}

Vidigal DJA, Silva AL, Fonseca LMA, Vasconcelos AC, Resende DF. Vidigal FEC. The effect of finasteride on spermatogenesis of Mesocricetus auratus. Acta Cir Bras. [serial on the Internet] 2008 May-June; 23(3). Available from URL: http://www.scielo.br/ $\underline{\mathrm{acb}}$

\footnotetext{
*Color figures available from www.scielo.br/acb
} 